into the supply of suitable films for children's performances. The Medical Panel has compiled a catalogue of British medical films and will issue supplements from time to time. The Scientific Research Panel is collecting material for a report on the extent to which the cinematograph is, and can be, used in the advance of scientific knowledge. The first Film Summer School for teachers was held at Scarborough last August. Ten local branches, known as Film Institute Societies, have been at work during the year, at Becontree, Bristol, Brighton, Chichester, Leeds, London, Manchester, Liverpool, Belfast and Salford.

\section{Research and the British Academy}

Prof. J. W. MackaIL, in his presidential address to the British Academy delivered in July last (Oxford University Press, pp. 11. 1s. net), laid it down as a principle that "the products of the Acaderny as an organised body . . . are all, in their different ways, and from their different angles and lines of approach, means towards an end", which he went on to define further as including two interlinked motives: to maintain a standard of learning and to preserve the continuity of civilisation. This view of the functions of the Academy would lay a heavy burden of responsibility on any body, however august; but if the further dictum be accepted that it is by the first that the second may be most directly and most effectively attained, it adds an impressive weight to the opinion the president expressed at an earlier stage in his address, that the Academy's grant from the Treasury of $£ 2,000$, only recently restored to its full amount, is quite inadequate. In the field of pure scholarship, certain enterprises, it is true, have been able to make progress through the Academy's subsidy. Yet even here, in what might be regarded as the Academy's special province, in number they make a poor showing. In the vast and wider fields of humanistic studies the prospect is even less encouraging. In archæological research, now that the excavations at Samaria have been brought to an end, apart from the contribution to the British School of Archæology in Iraq, which stands in a special category, the only body to which the Academy contributes is the British School of Archæology in Jerusalem. Archæological research unfortunately falls between the two stools of science and letters, belonging to the one by its technique, to the other in the applications of its results. This contention apart, in comparison with Continental academies, the British Academy is second to none in the standing of its fellowship ; but its material contribution, as a body, to the advancement of the subjects which have been brought within its purview is negligible.

\section{Mining in Tanganyika Territory}

WE have received an interesting pamphlet from Tanganyika Territory entitled "Mining Publicity Pamphlet", and issued by the Department of Land and Mines. It shows at the outset a useful map of the Territory, and after a short introduction there is full information for all prospective immigrants, including such points as the customs duties and the mining and prospecting laws which have been adopted. There is an account of the geology and physiography of the Territory, and economic minerals and mineral production are fully described. We find, for example, that the value of mineral production has increased largely and in many cases has doubled since 1932 when Great Britain went off the gold standard, with a correspondingly rapid rise in the price of the precious metal ; in fact, the value of all minerals has increased since 1932 with the exception of mica, which is less than half in 1934 what it was in 1932 ; whilst the value of the minerals produced is put down as close on $£ 200,000$ in 1932, in 1934 they

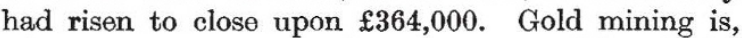
of course, a great attraction at present, although the pamphlet states that "it is to be anticipated that the internal prosperity it [gold production] is creating will exert its beneficial influence on other forms of mining within the territory". This is one of the few regions where the old-time prospector still finds work, and existing gold fields, containing both reef gold and alluvial gold, are fully described in the pamphlet in question. The pamphlet is of distinct use to immigrants proposing to enter Tanganyika Territory, and its perusal is strongly recommended to any who are proposing to go out, and especially perhaps to those intending to follow gold mining.

\section{The Spahlinger Tuberculosis Vaccine}

A JoINT committee on tuberculosis of the Medical Research Council and the Agricultural Research Council has issued in the form of a green paper (London : H.M. Stationery Office, 2d. net) observa. tions on the experiment with Spahlinger vaccine in Northern Ireland, the report on which was issued some weeks ago. In this experiment, 11 calves were vaccinated with the Spahlinger anti-tuberculosis vaccine, and 7 calves were kept unvaccinated as controls. Six months after the vaccination, all the calves were given the same dose of virulent tubercle bacilli intravenously. The difference in the effect on the two groups was striking. Of the 7 controls five died of acute tuberculosis within 25-73 days. On the other hand, none of the 11 vaccinated animals died from the acute disease, one died on the 607th day, and the remaining 10 lived until slaughtered on the 783rd-890th day. All, except one, of these were in good condition although found to be tuberculous to greater or less extent. The joint committee concludes that a case has been made out for further investigation, that the number of animals used in the Irish experiment were not enough to give statistically conclusive results, and that the general use of the vaccine should be deferred until a thorough investigation has been made.

\section{The Physique of Man in Industry}

IN 1927, the Industrial Fatigue (now Health) Research Board published a report of an inquiry on "The Physique of Women". The results of this inquiry appeared to be of such value that the Board decided to institute an investigation of the same kind 